\title{
COLLABORATIVE MANAGEMENT MODEL TANJUNG LESUNG TOURISM IN PANDEGLANG DISTRICT, BANTEN PROVINCE, INDONESIA
}

\author{
Kismartini KISMARTINI \\ Universitas Diponegoro, Department of Public Administration Jl. Prof. Sudharto, \\ SH, Tembalang, Semarang, Indonesia, 50275, e-mail: kismartini@live.undip.ac.id

\section{Bambang PUJIYONO*} \\ Universitas Budi Luhur, Faculty of Social and Political Science Jl. Raya Ciledug, Petukangan Utara, \\ Kebayoran Lama, Jakarta Selatan, Indonesia, 12260, e-mail: bambang.pujiono@budiluhur.ac.id
}

\begin{abstract}
Citation: Kismartini, K., \& Pujiyono, B. (2020). COLLABORATIVE MANAGEMENT MODEL TANJUNG LESUNG TOURISM IN PANDEGLANG DISTRICT, BANTEN PROVINCE, INDONESIA. GeoJournal of Tourism and Geosites, 30(2spl), 868-874.https://doi.org/10.30892/gtg.302spl12-516
\end{abstract}

\begin{abstract}
Community welfare, developing social potential, and environmental conservation are indicators of the success of The improving tourism management. Collaboration between the government, the private sector and the community is an important concept in tourism management. This study tries to explore the phenomenon of collaborative tourism management in Tanjung Lesung, Pandeglang, Banten Province of Indonesia. This study uses a qualitative method. Informants are 40 stakeholders representing government, private and community elements. In addition to interviews, data collection also uses observation and focus group discussions. The results showed that stakeholders were not yet mapped and tended to play a very dominant role in government and the private sector. While the community lacks a good role. The collaboration process faces obstacles due to differences in the capacity of each organization so that communication and coordination are hampered. This model is expected to be a solution to improve the collaboration process and collaboration performance in Tanjung Lesung tourism management.
\end{abstract}

Keywords: New approach of collaborative models, Management Tourism, Tanjung Lesung Indonesia

$$
* * * * * *
$$

\section{INTRODUCTION}

The Tanjung Lesung Tourism was determined by the government through PP No 26/2012. The presence of Tanjung Lesung Tourism SEZ which is located in the Pandeglang Regency is part of the central government's strategy in order to develop the domestic economy. With an area of 1,500 ha, Tanjung Lesung SEZ relies on the maritime-based tourism sector to support its business activities. Attractions available in the Tanjung Lesung SEZ include Ujung Kulon, Krakatau Mountain, ethnic Baduy, Panaitan Island, and Peucang Island.

Tourism has several benefits to the pro-poor economy, because: (1) consumers come to their destination, thus providing opportunities to sell goods and services, such as eyewear, (2) tourism providing opportunities to diversify the local community's economy, (3) ) tourism offers more intensive employment opportunities (Ashley, 2006; Sudiarta and Suardana, 2016). This is supported by the findings of the World Tourism Organization (2015) that show that tourism as an industry plays a role in creating both direct and indirect employment. Ashley (2006) further states that Pro Poor Tourism is a positive impact of tourism for the poor. Pro Poor Tourism is not a product but an approach to industry, where tourism is expected to increase participation in various sectors of tourism. Pro Poor Tourism aims to improve the economy of the community, increase the social benefits of tourism, and reduce the negative impact of tourism. Tourism management that cares for poverty in line with the mandate of the Republic of Indonesia's Law No. 10, 2009, that tourism aims to improve the economy of the people, the workforce and reduce poverty. Tanjung Lesung's tourism development policy explicitly flows from the central government through the RPJMN, the Master Plan Program for the Acceleration and Expansion of Indonesian Economic Development (MP3EI), RPJMD Banten Province, as well as being part of the vision and mission of Pandeglang Regency. Tanjung Lesung Tourism Special Economic Zone is one of the mainstays of national tourism which will contribute to the welfare of the community so that it can boost the human development index.

The existence of Tanjung Lesung tourism has a strategic significance for the Pandeglang district which is the empirical basis in this research, namely:

First, one of Pandeglang's vision is to become the center of tourism activities. It means, that Pandeglang Regency makes tourism a supporting sector to improve the regional economy. The government and all stakeholders will optimize the use of natural and cultural resources as tourism destinations, through the development of tourist attraction objects, promotion, and marketing, tourism services supported by the necessary infrastructure, guaranteed tourism regulations which are oriented to increase tourist visits and public welfare.

Second, stakeholders in the management of Tanjung Lesung tourism from government elements consist of the Central Government, Banten Provincial Government, and Pandeglang Regency Government. At the central government level, the Special Economic Zone (SEZ) Council is formed. The SEZ National Council is chaired by the Coordinating Minister for the Economy and consists of ministers or leaders of Non-Ministerial Government Institutions that are in charge of Local Government, Finance, Industry, Public Works, Trade, Labor, and others. The National Council subsequently forms the National Council secretariat which functions to determine general policies and strategic steps to develop SEZs and resolve strategic problems in the implementation, management, and development of SEZs.

Third, the Pandeglang Regency Government cooperates with the management of the Tanjung Lesung Special Economic Zone (KEK) to PT. Banten West Java (BWJ) Tourism Development. Fill out the agreement between the local government and PT. BWJ includes the rights and obligations of both parties as well as financing the implementation of the development of the Tanjung Lesung tourist area. The cost of implementing the SEZ development is the responsibility of PT BWJ Tourism Development. PT. BWJ as the manager has cooperated with domestic and foreign investors to accelerate the development process of the Tanjung Lesung SEZ. Within this SEZ development zone, locations for small and medium scale businesses must be prepared.

Fourth, Pandeglang Regency is one of the regencies in the Banten Province region that falls into the underdeveloped category. Several

* Corresponding author 
criteria make Pandeglang Regency lag behind aspects of the human development index, poverty level, level of economic development, and others (The Pandeglang Statistic of Office, 2015).

The description above, illustrates briefly, that tourism has good prospects for the welfare of people's lives. Tanjung Lesung tourism management involves a variety of stakeholders both government and private as well as different levels and sectorial communities.

Recognizing the synergistic tourism-landscape interaction is important because tourism generates income and employment opportunities that depend on the landscape, despite the simultaneous impact of tourism on the surrounding landscape (Heslinga et al., 2019; Buckley, 2012; Saarinen, 2006) and the community (King et al., 1993; Mc Combes et al, 2015; Snyman, 2016; Kanwal et al., 2020). Tourism is also an opportunity for nature protection because tourism plays a role in creating awareness, public support and in generating funds for nature protection (Libosada, 2009; McCool and Spenceley, 2014). To achieve natural protection and socio-economic development, we consider it important that synergistic interactions between tourism and protected areas are recognized and stimulated (Qiu et al., 2018).

Collaborative governance, which is at the root of the concept of "governance" (Stoker, 1998), arises after decades of debate about whether traditional government-based arrangements are able to solve the problems of contemporary society. The concept of collaborative governance has many interpretations when applied to the field of tourism (Bramwell and Sharman, 1999; Bramwell and Lane, 2011; Hall, 2011; Jamal and Getz, 1995; Scheyvens, 2011; Sharpley, 2010; Vernon et al., 2005; Zapata and Hall, 2012), rural studies (Jones and Little, 2000; Murdoch and Abram, 1998), and public administration (Emerson et al., 2012; Howlett and Ramesh, 2014).

However, in this study, collaborative governance refers to cooperation between state and non-state actors to regulate society efficiently and fairly (Keyim, 2016). State actors also referred to herein as "government" or "public sector," include publicly funded municipal, regional and supranational authorities, while the term private actor refers to members of the "non-government" or "private" sector. The underlying belief is that the socio-economic function of society can be more efficiently regulated through cohesive collaboration between the state and non-state actors rather than directed by the state alone.

Tourism management collaboration does not only involve public and private coordination but more often involves coordination between various public institutions that have jurisdiction in influencing the tourism sector. A good level of coordination between public institutions provides a better environment for developing collaboration with the public sector and civil society institutions and vice versa.

Most research on collaborative tourism management is related to tourism planning and policy (Bramwell and Sharman, 1999; Ladkin and Bertramini, 2002), public-public partnerships (Hall, 1998; Zapata and Hall, 2012), and sustainable tourism development (Waligo et al., 2013; Farmaki, 2015). The results of the study indicate that the tourism sector is increasingly networked and interdependent, there is a need to formally bring together various stakeholders to interact and achieve sustainable tourism development and contribute to poverty reduction.Based on the above description, it can be summarized that tourism management is in the domain of collaboration between government, the private sector, and the community. Thus the sustainability of tourism development and the contribution of the tourism sector in improving the welfare of the community/public becomes the responsibility of the three pillars of government that cross administrative and political boundaries and levels.Identification of problems can be identified as follow: first, many stakeholders are involved, have different functions and interests in Tanjung Lesung tourism management. This condition results in a non-integrated management that is fragmentation, sectoral, and has the potential for conflict between stakeholders; second, the collaborative process between organizations involved in Tanjung Lesung tourism management still has obstacles; third, Tanjung Lesung tourism management model has not been developed yet which can be used as a reference for the work of the stakeholders.

\section{LITERATUR REVIEW}

\section{Stakeholders and Collaborative Governance}

The position of this study is trying to present a collaboration model between tourism stakeholders. Relations between stakeholders are at the organizational level and different boundaries have taken place in tourism management activities. Some important dimensions that will be examined in this study include stakeholder relations, collaboration processes, collaboration activities, supporting and inhibiting factors, and recommended collaboration models. This study tries to broaden aspects of communication as part of the collaboration process so that it fills in the gaps in the importance of communication in the collaboration process. Stakeholder mapping was also conceived as an essential matter before collaborating. The study so far has been mapping stakeholders by using the same assumption that each stakeholder has a contribution. However, using mapping, stakeholders will be grouped with more appropriate criteria.

Conceptually, collaboration can be interpreted as variations. First, collaboration is a complex government job. Activities are carried out on a continuum and in gradations starting from collaboration, coordination, and collaboration (Emerson and Gerlak, 2014; Keast and Mandell, 2014). Second, collaboration is seen as a government strategy to solve very complex public problems (Ansell, 2016; Kekez et al., 2018). Third, collaboration is in the context of the mechanism and achievement of the collaboration itself (Fung, 2006; Ansell, 2016; Emerson and Nabatchi, 2015; Bryson et al., 2017; Nabatchi, 2017; Lahat and Hadar, 2019).

Collaboration theory refers to several experts namely Gray (1989), Mattessich et al. (2001), Agranoff and McGuire (2003), Bryson et al., (2006), Ansell and Gash, (2008), Vange and Huxham (2010), Doherty (2015). Based on this collaboration theory, researchers use relations between stakeholders to identify stakeholders, power, legitimacy, urgency (Ondee and Pannarunothai, 2008; Roussell et al., 2008; Todd et al., 2017; Pulido-Fernandez and Merinero-Rodríguez, 2018; Pujiyono et al., 2019).

Stakeholders in tourism management include individuals or groups who have power, influence, and interests. Stakeholders can influence each other in policy making (Waligo et al., 2013). Stakeholders have activities that refer to the tourism industry, environmental support, and the local community Pavlovich, 2003; Heitmann, 2010; Anuar et al., 2012; Turker et al., 2016). They consist of government, tourists, community, tourism business, media, and academics (Swarbrooke, 1999; Turker et al., 2016; Pujiyono et al., 2019).

Meanwhile, supporting factors and inhibitors of collaborative governance refer to the theory of linking organizational goals, comprehensive assessment, organizational value, administrative commitment, knowledge, and support (Reed and Cedja, 1987; Vange and Huxham, 2010); trust, shared believe, commitment (Agranoff, 2006), organizational, technical, and political constraints (Vaz and Silvia, 2003).

\section{Collaboration Process}

Raharja (2008) states that collaboration is a process carried out by involving many parties who carry out collective activities. Collaborative efforts as a primary method for short and long term ideas in order to achieve goals that cannot be achieved through work entities independently. Collaboration is a dynamic process. Collaboration occurs when an autonomous stakeholder group manages issues in an interactive process, uses the division of rules, structures, and norms, implements or decides on relevant issues (Vange and Huxham, 2010; Ansell and Gash, 2008). Collaborative activities consist of three stages as stated by Bradshaw, (1997) including problem sets, direction setting, and structuring. At the problem setting stage, the stakeholders realize that complex problems and interdependence of the organization 
must be overcome through joint efforts. At the direction setting stage, stakeholders work together to gather information and develop strategic planning. The plan that has been prepared is then carried out the distribution of power to all stakeholders so that it will influence the collaborative decision. At the structuration stage, the structure and process are determined to complement the shared goals within a framework that can guarantee the linkages of funding, communication, environmental mapping, and sustainable adaptation. The success of collaboration occurs incrementally, meaning that the success of the implementation of the collaboration agreement is very dependent on the collective ability of the stakeholders to manage change continuously.

As a dynamic concept, collaboration is an incremental process through several stages, namely the development of a collaborati ve vision that explains the common interests, the equalization, and understanding of collective experience, tools for achieving the best ways of working include finding the best, the vision that must be produced, the design of proposals that are feasible and can be applied.

\section{Collaborative Model Theory}

Weber et al. (2005) suggests that successful collaboration emphasizes the integration of various functions. This integration includes the function of the bureaucracy, across the policy arena and the level of government and involving citizens, communities and non-governmental organizations in problem solving and implementation processes.

There are three dimensions that he put forward: vertical dimension, horizontal dimension, and partnership linkage dimension. The vertical dimension reflects the relationship between government institutions and institutions, citizens and other non-governmental organizations in top-down relations. The horizontal dimension reflects the relations between equal organizations. Partnership linkage is described as blending (concoction) vertical-horizontal relations so as to produce an effective arrangement.

Agranof and Mc Guire (2003) introduce Jurisdiction-Based Model. This jurisdiction-based model is characterized by active collaborative activities on the vertical dimension. Meanwhile, the opportunistic collaboration strategy is on the horizontal dimension. The vertical dimension is the interaction of the activities and behavior of the actors who assume that interaction with other actors is part of their work, but the activity follows an external pattern. In this model bargaining and negotiation become important instruments. Haggling results in unilateral concessions and mutually beneficial solutions. The horizontal dimension explains that the process of policy making and governance (governance). In this realm no one has the power to determine the strategies of other actors because each has policies, strategies and operations that are specific to the conditions of the organization.

Based on the literature search, a collaborative governance formula was found which was introduced by collaboration experts. Anshell and Gash (2008) introduce the concept of collaborative governance which includes several factors, namely preconditions, institutional design, collaboration processes, facilitative leadership and results. These factors show the relationship to the collaboration process which will further influence the success of collaboration between organizations. Bryson et al. (2006) introduce the concept of collaborative governance including the general conditions of the organization, structure and governance, the process of collaboration, accountability, supporting and inhibiting factors and outcomes. Agranoff and Mc Guire (2003) introduced the concept of collaborative governance including collaboration activities, collaboration strategies, leadership, and collaboration models. Meanwhile, Gray (1989) introduced the concept of collaboration including four important things, namely the pre-condition of an organization, the process of collaboration, supporting and inhibiting factors as well as the interaction between collaboration actors.

The combination of the above theories becomes the conceptual basis of researchers to create a collaborative model in tourism management. The collaboration model will be developed based on conseptual and empirical data.

\section{Sustainable Tourism Management}

Research on collaborative governance in tourism is related to tourism planning and policy (Bramwell and Sharman, 1999; Ladkin and Bertramini, 2002; Nicolaides, 2014, 2015; Nicolaides and de Witt, 2015), public-public partnerships (Hall, 1998; Nicolaides, 2015; Zapata and Hall, 2012) and the development of sustainable tourism shows that the tourism sector is increasingly networked and interdependent (Farmaki, 2015). There is a need to formally bring together various stakeholders to interact and achieve sustainable tourism development and contribute to poverty reduction. Tourism has three important aspects that are needed, namely economic, social, and environment. They must be avoided from exploitation so that it does not have a negative impact. Exploitation of tourism based on natural resources causes environmental damage and damage the ecosystem in it. This damage will automatically negatively affect the economic and social aspects of tourism culture.

The idea of managing sustainable tourism is very important in order to overcome the negative impacts of tourism, by overcoming the problems of resource maintenance, ecosystem conservation, and physical capacity. Tourism must pay attention to environmental aspects (Wondirad et al., 2020; Gössling, 2002; Hunt, 2005). The concept of ecotourism as an alternative form of tourism is a continuity in tourism (Oriade and Evans, 2011). Tourism orientation has shifted from ecological to cultural tourism as seen from an economic and managerial perspective (Wondirad et al., 2020; Brown and Hall, 2008; Ko, 2005; Neto, 2003; Tyrrell and Johnston, 2008; Jayawardena et al., 2008).

Sustainable tourism is in a complex and dynamic space. Tourism must provide the needs of tourists, the tourism industry, without having to ignore the needs of future generations. Tourism sustainability requires firm policies and always prioritizes economic, social and environmental sustainability as important aspects (Scheyvens, 2011; Waligo et al., 2013; Farmaki, 2015).

Tourism development planning must meet economic, social, and environmental aspects as requirements that must be obeyed and implemented. This is very important in order to provide planned and sustainable tourism, in conventional and alternative forms that are based on economic, social and environmental sustainability principles (Farmaki, 2015; Berno and Bricker, 2001; Ruhanen, 2013). Sustainable tourism is a process of change that requires a balance between resource exploitation, investment direction and institutional change, sustainable development in tourism is inherently linked to the concept of governance. For example, Bramwell (2011) argues that effective governance can improve sustainable tourism goals in two ways. First, the inclusion of various stakeholders in decision making can strengthen democratic processes and responsibilities related to sustainable development. Second, tourism development can achieve economic, social and environmental goals of sustainability through effective governance if appropriate institutional arrangements and instruments are adopted.

\section{MATERALS AND METHOD}

Research using qualitative methods that reveal phenomena, actors, actions, and context refer to Creswell (2014). The research was conducted at the Tanjung Lesung tourism location, Pandeglang Regency, offered Indonesia. The research period is 6 months starting from the middle to the end of 2019. The focus of the research is on stakeholders, the collaborative process that takes place, as well as the resulting collaboration model based on empirical experience. Stakeholder mapping uses the dimensions of interests, influence and power of Onde, 2008; Ruson, 2008; Pujiyono et al., 2019). This mapping produces stakeholder groups in accordance with the optimal roles and functions in collaboration. The collaboration process is carried out by learning the empirical experiences of each institution involved in collaboration. 
The collaborative process is carried out by studying the phenomena and facts from the stages of initiation, development, and management of Tanjung Lesung tourism. Collaborative models are built by developing existing models (Anshell, 2007; Anshell and Gash, 2008) enriched through empirical data generated from the results of data collection. Data collection was carried out using in-depth interview techniques, filling in questionnaires from informants. The resource person was determined purposively and had direct involvement in the management of Tanjung Lesung tourism.Research sources included 40 stakeholders representing government, private and community elements. The research instrument uses direct observation techniques and structured interviews. Data processing is done in stages. In The first stage, get a tourism stakeholder mapping. The second stage reveals the process of collaboration between stakeholders. The third stage describes the tourism management model to build an ideal model based on data from the field.

\section{RESULT AND DISCUSSION}

\section{Collaboration on Tanjung Lesung Tourism Management}

After describing the data related to the management of Tanjung Lesung tourism, it is then summarized several important things which are the basis for the formation of the existing model. This existing model is based on a description of the implementation of management which includes who the stakeholders are, interactions between stakeholders, activities carried out, the collaborative process that occurs, as well as supporting and inhibiting factors. Tanjung Lesung tourism management involves stakeholders from government, private, and community elements. The government consists of the center, Banten Province, and Pandeglang Regency. The manager of Tanjung Lesung, namely PT. Banten West Java Development. The community consists of culinary entrepreneurs, lodging entrepreneurs, community leaders, religious leaders, NGOs, academics, mass media, batik craftsmen, village heads around, and Tanjung Lesung tourism connoisseurs. Each stakeholder has duties and functions in accordance with their respective roles in tourism management. The government provides infrastruct ure, provides facilitation in the development and management of amenities for the community. PT. BWJ develops and manages attractions for tourists and helps provide amenities and accessibility. The community's role is to support tourism activities in providing attractions and amenities. The involvement of the three stakeholder elements in the development and management of Tanjung Lesung tourism varies greatly, however, cooperation, communication, and coordination also develop at a still-low level. Relations between stakeholders occur vertically, horizontally, and diagonally. Internal relations between government organizations both central and local are vertical. Relations between the government and the private sector are carried out horizontally. The relationship between the government, the private sector, and the community is diagonal. These three types of relations are cross-sectoral and these characteristics have an impact on the collaboration process.

The collaboration process between stakeholders starts from the stages of initiation, development, to operationalization. The collaboration process is carried out through friendship, face-to-face activities, communication, building trust, establishing work plans, and socializing to the community. Forms of the agreement as a result of the collaboration between the government, private sector, and the community in the form of action plans agreed by stakeholders of the three elements.In the second stage of the collaboration process, and institutional communication activity was carried out. Communication that occurs in communication between groups or institutions represented by individuals. Individuals represent institutional interests. In this communication activity, a dialogue between stakeholders is established.

In this dialogue related to where the dialogue takes place, what role will be carried out in the dialogue, as well as how the dialogue process is managed. Collaborative processes between stakeholders in the development of Tanjung Lesung tourism are carried out through cooperation, coordination and communication activities. Coordination and communication were facilitated more by the Pandeglang districtlevel government and Banten Province. In this process, the dialogue is conducted openly for the participants of the dialogue in the hope that they can formulate together about the management of Tanjung Lesung tourism. Frequently, dialogue between stakeholders at different levels of the organization is rarely held. The district government has initiated more dialogue. Meanwhile, the private sector is more focused on finding investors who will be brought into the Tanjung Lesung area.Building collaboration in managing Tanjung Lesung tourism can be done through several steps including (1) Building the common view of collaborating with stakeholders, (2) Building strong collaborative institutions including memorandums of understanding and collaborative work agreements of all parties involved, (3) Building a conducive collaboration climate, (4) Presenting parties who are able to become initiators in guarding the collaboration process.

The role of community involvement in supporting the Special Economic Zone of Tanjung Lesung Tourism in tourism activities is still low, the community is not involved in making decisions about tourism activity planning. Communities around the Tanjung Lesung area are involved in tourism activities based on the potential of available resources but have not been coordinated in a programmed manner to support and benefit from the development of the Tanjung Lesung economic area. quality of cooperation that is built is very dependent on the capabilities of the coordinator in conducting facilitation and moderation. The authority for policymaking by the coordinator is limited to the administrative aspects of collaborative/secretarial management. The explanation above confirms that the aspect of 'institutional structure' in the framework of cooperation between agencies needs serious attention. The pattern of collaboration is determined by the choice between agencies to choose between hierarchical or networked. Both are based on how the decision-making process according to the aims and objectives of management will be built and implemented. Understanding of unequal and equal collaborative cooperation, related to aspects of coordination and communication. This means that the form of coordination in a hierarchical institutional structure with un-equal collaborative patterns of cooperation is ensured of a coordinative directive pattern. Furthermore, the form of communication in a hierarchical structure, aspects of cooperation are carried out through formal procedures.

The obstacle factor in collaborative management is due to the location disparity between stakeholders. Part of the stakeholders is at the center of the Pandeglang district government. Meanwhile, the community and managers are in the tourist location of Tanjung Lesung which is around $120 \mathrm{~km}$. Barriers to stakeholder meetings to follow up on agreed action plans are limited in their frequency and intensity. Even though there are SEZ Administration in the region, limited capacity is also an obstacle when making decisions regarding the implementation of the action plan that has been made. Sustainability of communication between stakeholders is repeated when the government initiates activities that are located around Tanjung Lesung such as the Tanjung Lesung festival and socialization for the buffer community. In these activities, carried out communication with other stakeholders. Other obstacles, conflicts arise and enlarge when collaboration activities take place. This conflict became an obstacle so that several locations were still disputed so that the development of tourism destination facilities was disrupted. Efforts to resolve land dispute problems involve the government, managers, and the community concerned.

Supporting factors in this collaboration are that stakeholders have the same goal in managing tourism to improve people's lives. The common goal is to strengthen cooperation, communication, and coordination. The ability of the government to collaborate with government agencies at the top level supports the implementation of this collaboration. Collaboration with the community for the government is easy because the government plays a role in providing guidance to the community, especially in the field of tourism development.

In such collaboration conditions, the contribution of Tanjung Lesung tourism has not met expectations in terms of output. But in the context of public involvement to solve public problems together, appreciation needs to be given. The government, the private sector and the 
community have contributed to the development and management of Tanjung Lesung tourism. The description above is in line with the opinions of the speakers as follows:

"By involving all selected tourism stakeholders, then discussing tourism management issues can be done with supervision, the interests of each stakeholder can be clearly detected, and consensus can be made, working in collaboration is very important because it can achieve interests despite competing with each other. Therefore, transparent, participatory and comprehensive discussion and formulation of win-win situations, competing / conflicting interests can be harmonized, and effective stakeholder collaboration can be realized" (informan, Cikadu Vilage).

\section{Description Collaboration Model}

Collaborative management has relative advantages. First, tourism management is based on multi-stakeholder shared interests. Second, collaborative management utilizes the knowledge, capability of resources, and capacity of each stakeholder so that there is an exchange of capacities for better management. Third, the fulfillment of equality and democracy aspects because the people's aspirations are heard and taken into account in decision making. Fourth, the possibility of fulfilling stakeholder desires in the concept of a win-win solution.

To guarantee the success of collaborative management, institutional support is needed. First, there is the support of social values that support cooperation. Second, the integration of community, private and government institutions. Third, administrative support and making rules regarding community rights. Fourth, financial support by the government and reduction of potential conflicts due to overlapping in management. Weber et al. (2005) argue that successful collaboration emphasizes the integration of various functions. This integration includes the function of the bureaucracy, across the policy arena and the level of government and involving citizens, communities and nongovernmental organizations in problem-solving and implementation processes.

There are three dimensions that he puts forward: vertical dimension, horizontal dimension, and partnership linkage dimension. The vertical dimension reflects the relationship between government institutions and institutions, citizens and other non-governmental organizations in top-down relations. The horizontal dimension reflects the relations between equal organizations. Partnership linkage is described as blending (concoction) vertical-horizontal relations so as to produce an effective arrangement.

In the vertical dimension, it can be seen that among stakeholders, the government involves the government from the central, provincial and district levels. The coordinating relationship between government agencies is, of course, hierarchical in nature. In implementing Tanjung Lesung tourism policy and management, each institution has a multilevel action plan. Thus, decision making related to the program or activity carried out must be based on direction and policy. That is, the implementation of management is based on a legal umbrella starting from the law, government regulations, ministerial regulations, governor regulations, and regent regulations.

On the horizontal dimension, relations between stakeholders occur in an unbalanced condition. Structurally, the degree of or ganization varies greatly between stakeholders. This varied condition is actually in the context of a collaboration known as multilevel collaboration. This condition faces difficulties in coordination because larger institutions are not yet open to other smaller organizations. Coordination takes place in a manner preceded by coordination with similar agencies in conflict, which can then be coordinated equally with other institutions.

On the environmental dimension, a collaboration between stakeholders has been established in a collaborative relationship, although within a small limit. According to the data collected collaboration took place in the preparation of an annual program for tourist attraction, the formation of the Tanjung Lesung FTKP as well as the licensing arrangement for the private sector that will invest in the Tanjung Lesung tourist area. Finally, this research proposes a new and holistic collaboration framework that integrates stakeholder theory and collaboration with management principles to develop sustainable tourism in developing countries.

This framework can serve as a blueprint for tourism stakeholders to consider environmental, social and economic elements as a shared agenda in their decision making, regardless of individual interests. Referring to the concept of collaborative governance and the results of field data analysis, the researcher will then describe the collaboration model. This conceptual collaboration management model for tourism is indeed not identical, but researchers acknowledge that the model offered is based on a combination of collaborative governance concepts Anshell and Gash (2008) and Bryson et al. (2006). Stakeholder mapping by Ondee and Pannarunothai (2008) was added to complement the existing Collaboration model. The model created by researchers can be seen in Figure 1.

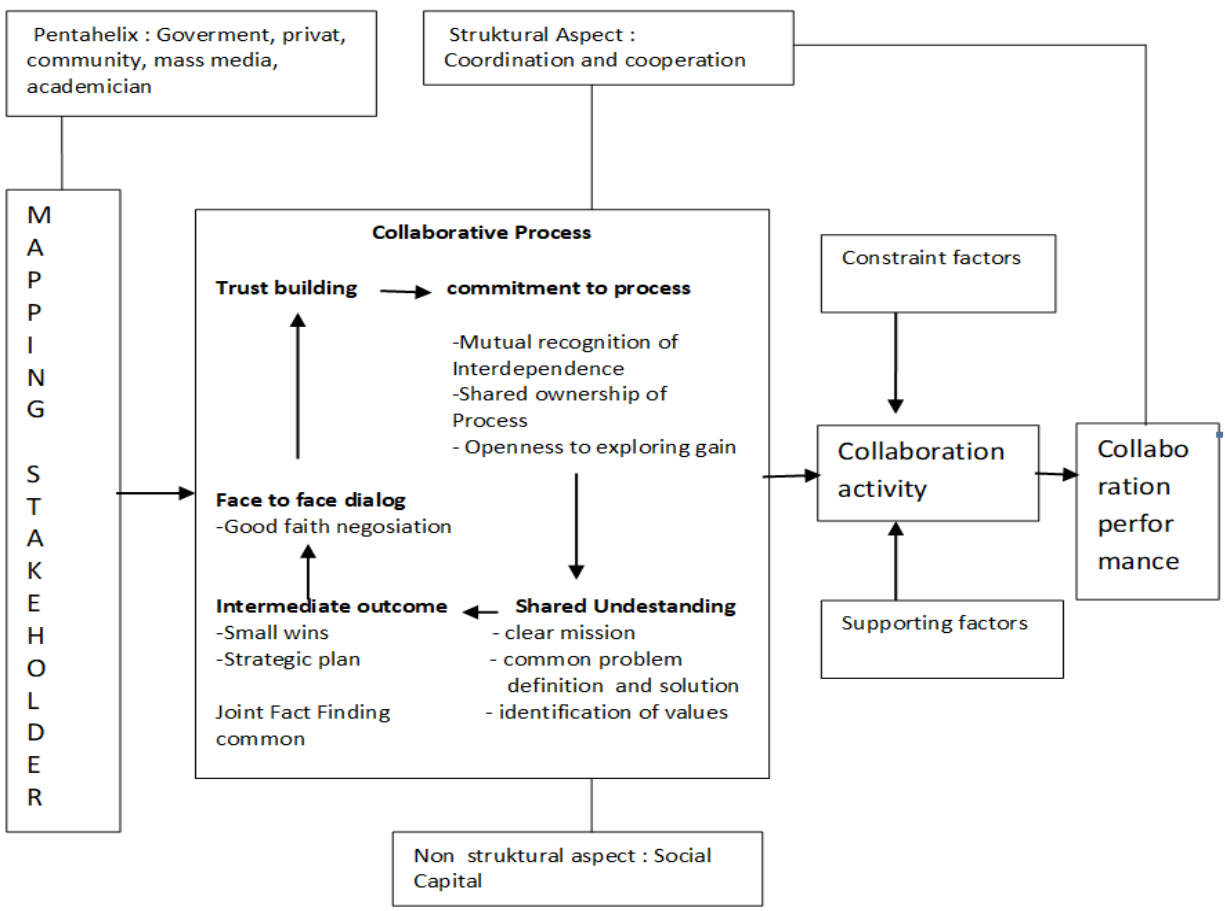

Figure 1. Management collaborative model on tourism 


\section{CONCLUSION}

Tanjung Lesung tourism management involves many stakeholders. Each stakeholder can directly carry out its role and function as an organization. Each organization has different interests that have an impact on the emergence of conflicts of interest. Tanjung Lesung tourism management is included in the type of collaboration but is at the lower level with characteristics still ego sectoral, there is no full openness between stakeholders, communication is not intense and dominance in activities is still happening.

The process of collaboration between organizations that have different levels of organizational capacity, in their implementation uses a coordination system. The process of collaboration, in general, has been carried out, although not yet ideal. Coordination is carried out in order to establish communication so that collaboration between stakeholders in the management of Tanjung Lesung tourism can proceed. The collaboration process takes place in the type of coordination in the equal organization. The collaboration process is helped by the existence of information, technology and communication infrastructure. Some factors that influence the collaboration of Tanjung Lesung tourism management include supporting factors and inhibiting factors. Supporting factors in this collaboration are more visible in the value of benefits felt by small institutions in the Tanjung Lesung tourism support community and the existence of the Tanjung Lesung Tourism SEZ government policy as a legal basis for collaborative management. Meanwhile, inhibiting factors include limited access to locations, organizational capacity, budget diversion and the ownership background of the Tanjung Lesung tourism area.

\section{RECOMMENDATIONS}

The government needs to change the way it collaborates with the private sector because it has different organizational capacities. Collaboration must be escorted by higher-level institutions so that they can become leading in collaboration and create interdependence. Every stakeholder must realize that collaboration must release ego sectoral so that collaboration can be realized. Openness, mutual trust, legitimacy, and sustainability of communication can be realized if stakeholders are willing to blend in the context of togetherness and interdependence.

\section{Implications Of Theory}

Theoretically, there are three theoretical implications obtained from this study, namely: first, describing the dynamics of tourism management that involves various stakeholders of different levels and across sectors both from government, private, and community elements; secondly, describing the importance of stakeholder analysis in collaborative management, thirdly describing comprehensive collaborative activities ranging from stakeholder mapping, collaboration processes, activities carried out up to determining supporting factors and inhibiting collaboration.

\section{Acknowledgement}

The authors would like to thank the following people for their valuable learnings and comments on this manuscript (Kismartini Kismartini and Bambang Pujiyono). Both of author have concern research in tourism, environment policy, and public management. The authors would also like to thank to the community of Pandeglang especially Cikadu Village.

\section{REFERENCES}

Agranoff, R. (2006). Inside Collaborative Networks: Ten Lessons For Public Managers. Public Administration Review, 66 (S1): $56-65$.

Agranoff, R., \& McGuire, M. (2003). Collaborative public management: New strategies for local governments. Georgetown University Press.

Ansell, C. (2016). Collaborative governance as creative problem-solving. Enhancing public innovation by transforming public governance, 35-53.

Ansell, C., \& Gash, A. (2008). Collaborative Governance in Theory and Practice. Journal of Public Administration Research and Theory, 18(4), 543-571.

Ashley, C. (2006). How Can Government Boost the Local Economic Impact of Tourism, option and too. For SNV East and Southern Africa. Overseas Development Institute.

Anuar, A., Habibah A., Hamzah J., \& Moh Y.H. (2012), Understanding the Factors Influencing Formation of Tourist Friendly Destination Concept. Journal of Management and Sustainability, Vol. 2, No. 1.

Berno, T., \& Bricker, K. (2001). Sustainable tourism development: the long road from theory to practice. International journal of economic development, 3(3), 1-18.

Bradshaw, L.K. (1997). Interagency Collaboration: preconditions, progress, and pressures. Paper annual meeting of American Evaluation Association, San Diego, USA.

Bramwell, B., \& Lane, B. (2011). Critical research on the governance of tourism and sustainability. Journal of Sustainable Tourism, 19(4-5), 411-421. doi:10.1080/09669582.2011.580586.

Bramwell, B., \& Sharman, A. (1999). Collaboration in local tourism policymaking. Annals of Tourism Research, 26(2), $392-415$.

Brown, F., \& Hall, D. (2008). Tourism and Development in the Global South: the issues. Third World Quarterly, 29(5), 839-849. doi:10.1080/01436590802105967.

Bryson, J., Sancino, A., Benington, J., \& Sørensen, E. (2017). Towards A Multi-Actor Theory of Public Value Co-Creation. Public Management Review, $19(5), 640-654$.

Bryson, J.M, Crosby, B., \& Stone M.M. (2006). The Design and Implementation of Cross - Sector Collaboration: Propositions from Literature. Public Administrative Review, 44-66.

Buckley, R. (2012). Sustainable Tourism: Research and Reality. Annals of Tourism Research, 39(2), 528-546.

Creswell, J.W. (2014). Research Design: Qualitative, Quantitative and Mixed Methods Approaches, (4 ${ }^{\text {th }}$ ed.). Thousand Oaks, CA: Sage.

Doherty, M. (2015). Factors of Successful Collaboration Oregon's Watershed Councils as Collaborative Systems. Resident Hatfield Fellow National Policy Consensus Center Portland State University.

Emerson, K., \& Gerlak, A. (2014). Adaptation in Collaborative Governance Rezim. Environtmental Management, 54(4), 768-781.

Emerson, K., Nabatchi, T., \& Balogh S. (2012). An Integrative Framework for Collaborative Governance. Journal of Public Administration Research and Theory, 22(1), 1-29.

Emerson, K., \& Nabatchi, T. (2015). Collaborative governance regimes, Washington, DC: Georgetown University Press.

Farmaki, A. (2015). Tourism Geographies. An International Journal of Tourism Space, Place and Environment, 17(3), 385-407.

Fung, A. (2006). Varieties of Participation in Complex Governance. Public Administration Review, 66(s1), 66-75.

Gray, B. (1989). Collaborating: Finding Common Ground for Multiparty Problems. San Francisco, Ca: Jossey-Bass.

Hall, C.M. (2011). Framing governance theory: A typology of governance and its implications for tourism policy analysis. Journal of Sustainable Tourism, 19(4-5), 437-457.

Hall, C.M. \& Jenkins. J. (1998). Rural Tourism and Recreation Policy Dimension. Chichester, John Wiley, 19 - 42.

Heitmann, S. (2010). Film Tourism Planning and Development-Questioning the Role of Stakeholders and Sustainability. Tourism and Hospitality Planning \& Development, 7:1, 31-46, DOI: 10.1080/14790530903522606

Heslinga, J., Groote, P., \& Vanclay, F. (2019). Strengthening governance processes to improve benefit-sharing from tourism in protected areas by using stakeholder analysis. Journal of Sustainable Tourism, 27(6), 773-787.

Howlett, M., \& Ramesh, M. (2014). The two orders of governance failure: Design mismatches and policy capacity issues in modern governance. Policy and Society, 33(4), 317-327. doi:10.1016/j.polsoc.2014.10.002.

Hunt, J. (2005). Capacity Building in International Development Context: implication for indigeneous Australia. paper, ANU.

Jamal, T.B., \& Getz, D. (1995). Collaboration theory and community tourism planning. Annals of Tourism Research, 22(1), 186-204 
Jayawardena, C., Patterson, D.J., Choi, C., \& Brain, R. (2008). Sustainable Tourism Development in Niagara: Discussions, Theories, Projects and Insights. International Journal of Contemporary Hospitality Management, 20(3), 258-277.

Jones, O., \& Little J. (2000). Rural Chalenges: Partnerships and New Rural Governance. Journal of Rural Studies, 16(2), 171 - 183

Kanwal, S, Hameed, P, Muhammad I.R, \& Adnan, P. (2020). Road and transport infrastructure development and community support forTourism: The role of perceived benefits, and community satisfaction. Tourism Management, https://doi.org/10.1016/j.tourman.2019.104014.

Keast, R., \& Mandell, M. (2014). The collaborative push: moving beyond rhetoric and gaining evidence. Journal of management \& governance, $18(1), 9-28$.

Kekez, A., Howlet, M., Ramesh, M. (2018). Varietas of Collaboration in Public Service. Policy Design and Practise.

Keyim, P. (2016). Tourism and Rural Development in Western China: A Case from Turpan. Community Development Journal 51(4), 534-51.

King, B., Pizam, A., \& Milman, A. (1993). Social Impacts of Tourism. Annals of Tourism Research, 20(4), $650-665$.

Ko, T.G. (2005). Development of a tourism sustainability assessment procedure: a conceptual approach. Tourism management, 26(3), 431-445

Lahat, L., \& Sher-Hadar, N. (2019). A threefold perspective: conditions for collaborative governance. Journal of Management and Governance, 1-18.

Ladkin, A., \& Bertramini, A.M. (2002). Collaborative tourism planning: A case study of Cusco, Peru. Current issues in tourism, 5(2), 71-93.

Libosada Jr, C. M. (2009). Business or leisure? Economic development and resource protection-Concepts and practices in sustainable ecotourism. Ocean \& Coastal Management, 52(7), 390-394.

Mattessich, P., M. Murray-Close \& Monsey, B. (2001). Collaboration: What Makes It Work, Amherst H. Wilder Foundation, St Paul, Minnesota.

Mc Combes, L., Vanclay, F., \& Evers, Y. (2015). Putting Social Impact Assessment to the Test as A Method for Implementing Responsible Tourism Practice. Environmental Impact Assessment Review, 55, 156-168.

McCool, S., \& Spenceley, A. (2014). Tourism and protected areas: A growing nexus of challenge and opportunity. Koedoe, 56(2), 1-2.

Murdoch, J., \& Abram, S. (1998). Defining the Limits of Community Governance. Journal of Rural Studies, 14(1), 41 - 50.

Nabatchi, T. (2017). Public Values Frames in Administration and Governance. Perspectives on Public Management and Governance, 1(1), 59-72.

Neto, F. (2003). A New Approach to Sustainable Tourism Development: Moving Beyond Environmental Protection. In Natural Resources Forum (Pp. 212222). Oxford: Blackwell Publishing Ltd.

Nicolaides, A. \& De Witt, L. (2015). Corporate Social Responsibility And Stakeholder Needs. In Management Innovation And Entrepreneurship: A Global Perspective, April 2015: Book Chapter 2: Edited By Demetris Vrontis, Georgia Sakka And Monaliz Amirkhanpour, Cambridge ScholarsPublishing: Uk.

Nicolaides, A. (2014). Authenticity and the Tourist's Search for Being. African Journal of Hospitality, Tourism and Leisure, 3(1).

Nicolaides, A. (2015). Tourism Stakeholder Theory in Practice: Instrumental Business Grounds, Fundamentantal Normative Demands Or A Descriptive Application. African Journal Of Hospitality, Tourism And Leisure, 4(2).

Ondee, P., \& Pannarunothai, S. (2008). Stakeholder Analysis: Who Are The Key Actors In Establishing And Developing Thai Independent Consumer Organizations. International Journal Of Human And Social Sciences, 3(4), 265-275.

Oriade, A., \& Evans, M. (2011). Sustainable and alternative tourism. Research themes for tourism, 69-86.

Pavlovich, K. (2003). The evolution and transformation of a tourism destination network: the Waitomo Caves, New Zealand. Tourism Management, 24(2), 203-216.http://dx.doi.org/10.1016/S0261-5177(02)00056-0 (retrieved 01.05.2020).

Pujiyono, B., Kismartini, K., Teguh, Y., \& Ida, H.D.M. (2019). Stakeholders Analysis on Tourism Collaborative Governance In Tanjung Lesung. African Journal Of Hospitality, Tourism And Leisure, 8(3).

Pulido-Fernández, J. I., \& Merinero-Rodríguez, R. (2018). Destinations' relational dynamic and tourism development. Journal of destination marketing \& management, 7, 140-152.

Qiu, H., Fan, D. X., Lyu, J., Lin, P. M., \& Jenkins, C. L. (2019). Analyzing the economic sustainability of tourism development: Evidence from Hong Kong. Journal of Hospitality \& Tourism Research, 43(2), 226-248. doi: 10.1177/1096348018777046.

Reed, R., \& Cedja, B. (1987). Attributes and preconditions of collaboration between and among schools, institutions of higher education, and state education agencies. Elmhurst, IL: North Central Regional Laboratory.

Ruhanen, L. (2013). Local Government: Facilitator Or Inhibitor Of Sustainable Tourism Development. Journal of Sustainable Tourism, 21(1), 80-98.

Roussel, S., Koutrakis, E.T., Sapounidis, A., Marzetti, S., Giuliani, V., Martino, S., Fabiano, M., Malvárez, C.G. (2008). Public c Stakeholders’ Perception of ICZM and Coastal Erosion in the Mediterranean. Coastal Management, 38:354-377.

Saarinen, J. (2006). Traditions of Sustainability in Tourism Studies. Annals of Tourism Research, 33(4), 1121-1140.

Gössling, S., Hansson, C.B., Hörstmeier, O., \& Saggel, S. (2002). Ecological footprint analysis as a tool to assess tourism sustainability. Ecological economics, 43(2-3), 199-211.

Raharja, S.U.J. (2010). Pendekatan Kolaboratif Dalam Pengelolaan Daerah Aliran Sungai Citarum. Jurnal Bumi Lestari, 10(2), $222-235$.

Scheyvens, R. (2011). The challenge of sustainable tourism development in the Maldives: Understanding the social and political dimensions of sustainability. Asia Pacific Viewpoint, 52(2), 148-164.

Sharpley, R., \& Naidoo, P. (2010). Tourism and poverty reduction: The case of Mauritius. Tourism and Hospitality Planning \& Development, 7(2), 145-162.

Snyman, S. (2016). Strategic community participation in sustainable tourism. In Reframing sustainable tourism (pp. 65-80). Springer, Dordrecht.

Sudiarta, I.N., \& Suardana, I. W. (2016). Dampak Pariwisata Terhadap Kemiskinan di Kawasan Pariwisata di Bali. Dalam Jurnal Kajian Bali, 6(02), 209 - 227.

Swarbrooke, J. (1999). Sustainable Tourism Management. Cabi Publishing: New York.

Todd, L., Leask, A., \& Ensor, J. (2017). Understanding primary stakeholders' multiple roles in hallmark event tourism management. Tourism management, 59, 494-509.

Turker, N., Faruk, A., \& Ali, S.C. (2016). The Role Stakeholder in Sustainable Tourism Development in Safranbolu Turkey, HLST Summer, Tokyo Japan.

Tyrrell, T.J., \& Johnston, R.J. (2008). Tourism Sustainability, Resiliency and Dynamics: Towards A More Comprehensive Perspective. Tourism and Hospitality Research, 8(1), 14-24

Vange, S., \& Huxham, C. (2010). Introducing The Theory Of Collaborative Advantage. The New Public Governance Emerging Perspectives on The Theory And Practice Of Public Governance. Stephen P. Osborne (Ed.) New York: Routledge, 163-184.

Vaz, P., \& Silvia, D. (2003). Converners as Champions of Collaboration in Public Sector: a case from South Africa. Journal of Public Administration and Development, 23(2) $141-150$.

Vernon, J., Essex, S., Pinder, D., \& Curry, K. (2005). Collaborative Policymaking: Local Sustainable Projects. Annals of Tourism Research, 32(2) 325-345

Waligo, V.M., Clarke, J., \& Hawkins, R. (2013). Implementing sustainable tourism: A multi-stakeholder involvement management framework. Tourism management, 36, 342-353.

Weber, E.P., Lovrich, N.P., \& Gaffney, M. (2005). Collaborative Enforcement, A Framework For Assessing Collaborative Problem Solving. Journal Society Dan Natural Resources.

Wondirad, A., Tolkach, D., \& King, B. (2020). Stakeholder collaboration as a major factor for sustainable ecotourism development in developing countries. Tourism Management, 78, 104024.

Zapata, M.J., \& Hall, C.M. (2012). Public-private collaboration in the tourism sector: balancing legitimacy and effectiveness in local tourism partnerships. The Spanish case. Journal of Policy Research in Tourism, Leisure and Events, 4(1), 61-83.

*** World Tourism Organization. 2015. Global Forecast and Profiles of Market Segments.

*** the Republic of Indonesia's Law No. 10, 2009 about Tourism in Indonesia.

*** Statistic of Pandeglang District, Statistic Pandeglang Office, 2015. 